\title{
Det känslomässiga utbytet och omsorgskvalitet i hemtjänsten
}

\author{
BENGT INGVAD \& ERIC OLSSON
}

Förväntningarna på utbytet av omsorgsarbetet har en central betydelse för dynamiken i hemtjänsten. Parterna hanterarvanligen olikheter i förväntningarna så att utbytet blir tillfredsställande. Dock ingår i vårdbiträdets hantering sociala konstruktioner som idealiserar omsorgsarbetet och tillskriver parterna egenskaper och roller. Konsekvenserna analyseras i denna artikel utifrån ett socialpsykologiskt perspektiv.

Hjälp och omsorg till äldre människor inom hemtjänsten kan tyckas vara lätt att beskriva och definiera. Vid närmare granskning visar sig denna praktik emellertid utgöra en mångfacetterad process där en komplicerad relation upprättas och starka positiva och negativa känslor kan vara involverade. Det är inte självklart att begära hjälp av en annan

Bengt Ingvad är doktorand vid socialhögskolan i Lund och bedriver forskning kring omsorg om äldre.

Eric Olsson är docent i socialt arbete vid socialhögskolan i Lund och bedriver forskning och utvecklingsarbete kring organisationsförändringar och gruppers dynamik.

Eric Olsson och Bengt Ingvad arbetar f.n. på ett forskningsprojekt om beslutsprocesser kring bistånd i hemtjänsten. människa med sin privata livsföring, förflyttning eller personliga hygien. Det är inte heller självklart för en person som bistår hur man ska gå tillväga för att den andra parten ska få adekvat hjälp och uppleva tillfredsställelse. De känslomässiga upplevelserna i situationen påverkar parterna, villka har förväntningar på ett positivt resultat av omsorgen. I ett forskningsprojekt studerar vi olika aspekter på denna hjälprelation (Olsson \& Ingvad, 1992). Huvudfrågan är vilken bety-

Denna artikel bygger på forskning finansierad avHSFR (F 195/92) och SFR (94-0062:1C,970362:1C). Vi vill framföra ett tack till Berit Mattisson för arbetet med utskrifterna av intervjuerna. 
delse karaktären i relationen mellan vårdgivare och vårdtagare har för kvaliteten i den omsorg som förmedlas. I'denna artikel presenterar vi en intervjustudie av hur vårdbiträden $\mathrm{i}$ hemtjänsten uppfattar relationen till vårdtagaren.

ISverige har både hemtjänst och institutionell vård för de äldre byggts ut under 1960- och fram till andra hälften av 1970talet, medan båda hjälpformerna har minskat i omfattning under 1980- och 1990-talet, trots att andelen 80 år och äldre $(4,5$ procent av den totala befolkningen) har ökat med 60 procent sedan 1980 . Utvecklingen har lett till att många fler mycket gamla och sjuka idag vårdas i hemmet av anhöriga och av hemtjänsten. Bland de som var 80 och äldre 1996 bodde 25 procent av kvinnorna och 18 procent av männen på institution, medan 22 procent av kvinnorna och 16 procent av männen hade hemtjänst i sitt eget hem (Szebehely, 1998). Under 90-talet har hemtjänsten i många kommuner genomgått en kraftig omorganisation, bl.a. har ansvaret för biståndsbesluten och omsorgsarbetet delats upp i beställare och utförare, försök har gjorts att platta ut organisationen, och delar av omsorgsarbetet har lagts ut på entreprenad (Olsson \& Ingvad, 1998a). I arbetsgrupperna, drivna i kommunal eller privat regi, organiserar vårdbiträdena vanligen omsorgsarbetet på egen hand och har regelbundna arbetsplatsmöten kring arbetet med vårdtagarna.

\section{Studier av relationer i hemtjänsten}

Vi antar att en relation innebär att två personer i ett samspel påverkar varandra. För- ändringar i tankar, känslor eller handlingar hos den ena personen ger upphov till och påverkas av förändringar hos den andra personen. Därmed skapas i inledningen av interaktionen en relation, som kan utvecklas. Karaktären i en relation betingas, förutom av de sociala och fysiska omständigheterna, av hur personerna påverkar varandra och av de föreställningar och förväntningar kopplade till mötessituationen som personerna bär med sig. Vi antar att interaktionen bestäms av hur dessa faktorer växelverkan (se Lewin, 1952).Vid sidan om att samspela med och uppleva varandra innebär en relation också att parterna konstruerar en föreställning om ett gemensamt »vi«. Denna konstruktion, som innebär att parterna bekräftar att de delar ett gemensamt upplevelsefält (Asch, 1952), har avgörande betydelse för parternas förhållningssätt, attityder och handlingsmöjligheter i mötet (Olsson, 1989).

\section{Den formella omsorgsrelationens dynamik}

Relationen mellan vårdbiträdet och vårdtagaren innehåller formella och informella aspekter. Parterna är från början oftast främlingar för varandra, sammanförda genom ett formellt avtal om bistånd, baserat på en lagstadgad rättighet (Challis \& Davies, 1986). Utgångspunkten är att vårdtagaren inte till fullo kan klara av sin vardagssituation på egen hand.Vårdbiträdet har ingått ett avtal med en organisation att mot lön genom vård, hjälp och stöd komplettera vårdtagarens resurser. Mötet är påtvingat och reglerat, varken vårdtagaren eller vårdbiträdet har kunnat välja den andra parten, och deras möten är fastställda av arbetsprinciper 
och scheman. Omsorgsarbetet i hemtjänsten är ofta fråga om ett möte mellan två kvinnor, och arbetet tillhör traditionellt kvinnors oavlönade omsorgsarbete inom familjen, fastän i hemtjänsten är familjearbetet överflyttat till ett annathem (Szebehely, 1995). Verksamheten kan därför tänkas bli påverkad av den traditionella synen på manligt och kvinnligt. Bergh (1995), t.ex., framhåller att pensionärerna ofta har olika förväntningar på manliga och kvinnliga vårdbiträden. Flera författare betonar betydelsen av att arbetet är offentligt avlönat (se t.ex. Simonen, 1990; Szebehely, 1995). Därmed får vårdbiträdets arbete en unik karaktär genom att befinna sigi gränsområdet mellan det offentliga och det privata.

Omsorgsarbetet får en specifik innebörd genom att det utförs avskilt i någon annans privata hem (Barer, 1992). Szebehely (1995) påpekar att hemmet är förknippat med idealbilder som »den goda husmodern« och "den goda modern . Dessa kan prägla vårdbiträdets normer för arbetet genom insatsernas likhet med omsorg inom familjen (Szebehely, a.a.).I hemmetär dessutom parternas roller flertydiga (Barer, 1992). Den gamle kan, t.ex., bli osäker på om hon uppfattas som en arbetsgivare, värdinna, kund eller skyddsling. Ska vårdbiträdet uppfattas som en hjälpande medmänniska, väninna, offentligt anställd eller hembiträde (Barer, a.a.)? Till hemmets sociala liv hör känslomässiga, familjemässiga och personliga dimensioner, exempelvis identitet, kontroll och bekräftelse. Dessa dimensioner är nödvändigt inneslutna i de praktiska sysslor som utförs i ett hem, de manifesteras under vårdbiträdets arbete i hemmet (Kaye, 1986) och kan då leda till konflikter. Hemmet kan sålunda sägas bestå av betydelsefulla vanor, roller och ritualiserade handlingar som påverkar omsorgsarbetet (Thomas, 1986). Inköp av mat, t.ex., kan tyckas vara något okomplicerat, men denna handling kan tillhöra en av de svårare uppgifterna för vårdbiträdet att utföra genom de laddningar som finns kring att handha pengar och att välja varor (Bartoldus m.fl., 1989).

Omsorgsrelationen kan till en början vara ytlig, men karaktären i relationen kan förändras över tiden. De formella aspekterna bidrar till att skapa distans mellan parterna, bl.a. det sätt arbetet är organiserat på. Inledningsvis ger de mötet struktur och underlättar samspelet (Qureshi, 1990). Författaren fann i sin studie att en del äldre bara ville ha de praktiska sysslorna utförda. I dessa fall uppfattade hjälparna karaktären i relationen som relativt ytlig: man gjorde vad man skulle och gick sedan. I andra fall byggde de två parterna upp en nära relation. (Qureshi, a.a.).Kaye (1986) antog att lång anställningstid skulle gynna en distanserad och rutinmässig hållning gentemot vårdtagarna. Så var inte fallet. Snarare ökade vårdbiträdets positiva känslor för vårdtagarna med hennes anställningstid. Författaren drar slutsatsen att varken anställningstid eller organisationens arbetskrav reducerar vårdbiträdenas känslor för pensionärerna. Detta kan förstås som ett resultat av en liering mellan vårdbiträdet och vårdtagaren (se Olsson, 1988; Kronvall m.fl., 1991). Hjälpmottagarens krav och önskningar påverkade arbetstagaren mer än kraven från arbetsgivaren. Arbetstagarna kan stärka sin position genom attliera sig med klienterna, något som i sin tur gynnar utvecklingen av nära relationer i omsorgsarbetet. 
Nära relationer i hemtjänsten beskrivs av t.ex. Friedman Rosenfeld \& Kaye (1979) och Chichin (1992). Vänskap, föräldra-barnrelationer, etc, innebär en hög grad av ömsesidigt beroende mellan parterna (se t.ex. Kelley m.fl., 1983; Olsson, 1998). Levinger (1983), som studerat parbildning mellan könen, menar att förutsättningen för uppkomst och etablering av en nära relation är att parterna upplever någon form av symmetri i handlingar, känslor eller sätt att tänka. Uppbyggnaden förefaller gå genom en serie faser där avbrott, stagnation eller sammanbrott kan äga rum. Peterson (1983) framhåller i ett arbete om konflikter i parförhållanden att dessa kan bli avgörande för förändringar av relationen.

\section{Utbytet i omsorgsrelationer}

Genom omsorgsarbetet ingår vårdbiträdet och vårdtagaren $\mathrm{e}$ ett förhållande med ett praktiskt, socialt och känslomässigt utbyte på gott och ont. Omsorg om en annan människa beskrivs ofta som ett arbete att sörja för och med vårdtagaren. Detta arbete kan vara både fysiskt och psykiskt påfrestande (se t.ex. Thulin, 1987). Pensionären kan hjälpa till i det praktiska arbetet, som försvåras om samarbetet uteblir. I en del fall kan den äldre stå för ett betydelsefullt socialt och emotionellt stöd för vårdbiträdet, $i$ andra fall kan vårdbiträdet uppleva sig socialt underordnad eller känslomässigt utsatt.

Hos båda parter tycks det finnas förväntningar på hur utbytet ska gestalta sig. I en studie av betalda anhörigvårdare var känslan av uppskattning från vårdtagaren, andra personer eller samhället den viktigaste faktorn för upplevelsen av en högre grad av glädje och tillfredsställelse i omsorgsarbetet
(Furåker \& Mossberg, 1997). Även i hemtjänsten tycks den uppskattning eller kritik man får av pensionären upplevas som viktig (se Eliasson m.fl., 1984a, 1984b), och vårdbiträdets gensvar på pensionärens hållning tycks få motsvarande innehåll. Författarna skriver att, om vårdbiträdet har möjlighet attlära känna den gamla, är den personliga kontakten, lärandet, uppskattningen och känslan av att ha gjort nytta det som skänker tillfredsställelse i arbetet. Om pensionären upplevdes som orättvis, otacksam, fordrande eller krävande, kunde vårdbiträdet bli irriterad, arg eller ledsen. Till de pensionärer där situationen upplevdes ge mest psykiska påfrestningar hörde de psykiskt sjuka, alkoholiserade, nedlåtande och de kontrollerande (Eliasson m.fl., a.a.). I en annan studie berättade vårdbiträdena att kontakten var problematisk och svår med bl.a. de vårdtagare som upplevdes som bittra, beroende, klagande och där man kände att man inte räckte till (Thulin, 1987). I en studie av Kaye (1986) upplevdes vårdtagarna ha förväntningar på emotionellt stöd, oberoende av vilken hjälp de var beviljade. Vårdbiträdena uppfattade att vårdtagarna hade starkare känslor för vårdbiträdena än vad de uppgav att de kände för vårdtagarna (Kaye, a.a.). Detta tyder på att vårdbiträdena hade en önskan om ett känslomässigt gensvar från vårdtagarna. Lindqvist (1995) menar att vårdbiträdet likt andra har ett emotionellt behov av att få känna sig duktig, omtyckt och behövd. Han fann att nöjda vårdtagare-om mötet bekräftade vårdbiträdet - fick mer tid av vårdbiträdena än besvärliga och missnöjda vårdtagare, medan de faktiska behoven var de omvända. Pensionärer som inte har sina grundläggande behov av 
t.ex. trygghet tillgodosedda är ofta missnöjda med den hjälp de får. Det är svårt för vårdbiträdet att tillgodose vårdtagarens behov och därmed också de egna emotionella behoven, och mötet kan bli ångestskapande. Dessa vårdtagare förstärker föreställningar hos vårdbiträdet om att det är svårt att hantera beroende, hjälplöshet och lidande när man åldras (Lindqvist, a.a.).

Makt, en i övrigt central aspekt av dynamiken i relationer, är en ständigt närvarande dimension av utbytet mellan vårdbiträdet och vårdtagaren. Wærness (1983) menar att det som kännetecknar omsorgsarbete, både inom familjen och i t.ex. hemtjänsten, är att mottagaren inte själv kan klara de tjänster hon eller han får hjälp med. Omsorgen baseras på ansvar och skyldighet hos givaren, och mottagaren är underordnad. Detta maktförhållande samt omsorgsgivarens grad av autonomi $i$ arbetet bestämmer enligt Wærness (a.a.) karaktären i dessa omsorgsrelationer.Vi menar dock att detär väsentligt att ta hänsyn till den kraft med vilken båda parter kan påverka den andra eller motstå påverkan i relationen - ett synsätt som utgår från Lewin (1952). Dåär det möjligt att djupare förstå hur parternas sociala positioner kan upphäva den gamlas lägre status, vilket Szebehely (1995) fann. Även Christensen (1991) fann att vårdbiträden upplevde sig underordnade resursstarka vårdtagare och vårdtagare med höga krav på hushållsarbetet; samspelet upplevdes som positivt med pensionärer de intekände sig underordnade. Möjligen kan vårdbiträden också uppleva sig underordnade de vårdtagare som inte blir nöjda: En finsk undersökning av hemvården (Raatikainen, 1991) visade att äldre vårdtagare som var missnöjda med hjälpen upplevdes som impopulära och motsträviga av personalen (läkare, sjuksköterskor, vårdbiträden i hemtjänsten). Författaren antar att denna situation förstärktes genom en ond cirkel mellan vårdtagarens otrygghet och missnöje och vårdgivarens upplevelse av att vårdtagaren inte ville samarbeta.

Inära relationer är parterna i högre grad berörda av utbytet.Att utbytet upplevs som (positivt) symmetriskt blir betydelsefullt. Mellan makar, t.ex., råder vanligen multipla beroendeförhållanden och över- och underordningar. Studier av informell omsorg har visat att omsorgsgivaren upplever omsorgsarbetet som tillfredsställande om båda makar är eller har varit givare och mottagare och utbytet upplevs som symmetriskt (Wenger, 1987; Parsons m.fl., 1989). Gordon \& Easton (1993) fann atti symmetriska omsorgsrelationer upplevde båda parter ett egenvärde och en bevarad värdighet. Även $\mathrm{i}$ hemtjänsten kan båda parter uppleva symmetri i utbytet, trots vårdtagarens underläge i förhållande till organisationens makt över det arbete som ska utföras. Qureshi (1990), t.ex., beskriver vänskapsliknande bindningar mellan vårdtagaren och hjälparen. Dessa var ofta utvecklade med de pensionärer som hade något att erbjuda i gengäld till hjälparen och där utbytet upplevdes som symmetriskt av båda parter. Författaren anser att ett av motiven för vårdtagarna att ge ett positivt känslomässigt gensvar till hjälparna var att de ville vara säkra på att den tillgivenhet de fick var äkta. Det känslomässiga gensvaret från vårdtagaren var viktigt för hjälparna (Qureshi, a.a.). Dessutom kan vårdbiträdets lön från det offentliga tänkas påverka utbytesförhållandet

Ingvad \& Olsson: Det känslomässiga utbytet och omsorgskvalitet. . . 
mellan parterna. Pensionären kan uppleva attlönen i viss mån kompenserar vårdbiträdet för bristen i ömsesidighet, medan den för vårdbiträdet kan ge en känsla av ett visst oberoende av vårdtagaren. Även om parterna från början upplever en symmetri i utbytet, kan en obalans utvecklas. Vårdbiträdet kan t.ex. uppleva att vårdtagaren är kravfylld och utnyttjar henne (se bl.a. Challis \& Davies, 1986; Eustis \& Fischer, 1991).

\section{Konflikter och konflikthantering}

Ett flertal studier kring hemtjänsten pekar på konflikter kring förväntningarna på utbytet. Kaye (1986) fann att vårdtagarnas förväntningar på emotionellt stöd och personliga råd var de vanligaste konfliktanledningarna. Svårast att hantera var de vårdtagare som upplevdes ha stora känslomässiga behov.I en annan studiekände vårdbiträdena krav på sig att svara med en emotionell stödinsats då vårdtagarna uttryckte känslor av sorg, ensamhet och negativism (Bartoldus m.fl., 1989). Det som upplevdes svårast att hantera vara de känslomässiga och relationella aspekterna av arbetet. I denna amerikanska undersökning upplevde man också stark kritik och klagomål från vårdtagarna. Några angav i intervjun att de blivit utsatta för hot, fysiskt våld och sexuella närmanden.

Konflikter kan hanteras genom maktutövning. Szebehely (1995), t.ex., fann att pensionärer som upplevde att deras behov inte tillfredsställdes försökte uppnå detta genom att bl.a. betona sin svaghet, för att väcka medkänsla, eller genom att kontrollera vårdbiträdets arbete. Ingvad (1992) visar att vårdtagare i en del fall försöker undvika eller dämpa konflikter kring det förväntade utbytet genom att undanhålla sitt missnöje och inta en förnöjsam inställning i mötet med vårdbiträdet. Även om de är kritiska till organisationen, resonerar de med sig själva och kommer fram till att man får vara nöjd. Ett viktigt skäl var att man inte vill rubba en positiv relation till vårdbiträdet.

Genom sitt inflytande över arbetet har arbetsorganisationen makt över vårdbiträdets och vårdtagarens möte. Organisering av ledarskap, ansvarsfördelning, gruppstorlek och mötesordning har betydelse för arbetsklimat och uppkomst och hantering av konflikter med pensionären (Olsson m.fl., 1995). Författarna har bl.a. funnit atti arbetsgrupper där vårdbiträdena upplever samspelet i gruppen som splittrat upplever vårdtagarna i större utsträckning relationen till vårdbiträdet som otrygg (Olsson \& Ingvad, 1998a). I en traditionell arbetsgrupp, där bl.a. arbetsuppgifterna i låg grad var förhandsstyrda, visar Szebehely (1995) att den relativa över- och underordningen mellan pensionären och vårdbiträdet var en öppen fråga. Vårdbiträdena i en självstyrande smågrupp med resursstarka vårdtagare upplevde en konflikt i mötet med pensionärema mellan närhet och underordning (Szebehely, a.a.).Vårdbiträdena hanterade denna konflikt genom undvikande. Arbetet i gruppen organiserades utifrån principer om ett kollektivt ansvar och undvikande av personliga band, vilket ledde till att känslorna av närhet och underordning minskade.

Maktutövning och tvång kan i sällsynta fall leda till en extrem upptrappning av en konflikt mellan vårdbiträdet och vårdtagaren. Andra aktörer - en arbetsgrupp som sluter sig samman, arbetsledare, anhöriga, etc. -kan bli indragna i konflikten. Två mot- 
ståndarläger kan uppstå med starka negativa känslor gentemot varandra. I denna situation förefaller inte någon av parterna ha förmåga att se kritiskt på sin egen roll eller reflektera över skeendet (Olsson \& Ingvad, 1992).

\section{Utgångspunkter och syfte}

Av ovanstående litteraturgenomgång är det tydligt att omsorgsrelationen är sammansatt av sociala och känslomässiga krav och att den innehåller en dynamik kring utbytet mellan parterna. Det kan finnas stora skillnader i förväntningar på detta utbyte, och samspelet kring dessa olikheter kan antas utgöra ett viktigtled i uppbyggnadsprocessen av omsorgsrelationen. Skillnaderna utgör latenta konflikter, dvs de är meningsskiljaktigheter som ännu inte utlöst känslor och handlingar. Dessa latenta konflikter kan förstås utifrån det vi kallar ett utbytesteoretiskt perspektiv. Dowd (1975) har tidigare formulerat en teori kring utbyte av tjänster som går ut på att individer som tillsammans ingår i ett socialt samspel har rättigheter och skyldigheter i förhållande till varandra. Individen strävar efter balans i utbytet med andra människor, och parterna förväntar sig attbli återgäldade i förhållande till vad man givit. Studier har visat att obalans i utbytet bl.a. kan leda till beroende samt känslor av otillfredsställelse och ensamhet hos äldre kvinnor (Rook, 1987).Vi antar i denna studie att vårdbiträdet och vårdtagaren strävar efter balansi upplevelsen av helheten av det praktiska, sociala och emotionella utbytet.

Man kan i de flesta mellanmänskliga sammanhang urskilja olika typer av spontana strategier för konflikthantering, vilka bi- drar till att utforma den sociala verklighet utifrån vilken vi tolkar och bemöter varandra i det vardagliga samspelet (Olsson, 1988). Det vanliga mönstret för konflikthantering är att parterna efter inledande kraftmätningar finner vägar till överenskommelser genom mer eller mindre öppna förhandlingar. Om parterna inte är beredda att överge kraftmätningen kan konflikten trappas upp. De söker då genom destruktiva handlingar nå ett överläge eller vinna över varandra. Maktutövning och tvång men också undvikande, nedtystning eller uppskjutande av konflikten utgör vanliga konflikthandlingar. Det är således viktigt att skilja ut konfliktanledningen från de handlingar som konflikten leder till. En konflikt ger upphov till känslomässiga påfrestningar hos parterna. Vid upptrappade konflikter finns det en tendens att den ursprungliga konfliktanledningen blir ointressant medan parterna blir upptagna av att vinna och utöva kontroll över varandra (Olsson, a.a.).

På en arbetsplats har medarbetarna utformat mönster för samspel och konflikthantering.Vårdtagarens hem, vårdbiträdets arbetsplats, tillhör vårdtagaren. Där har familjemedlemmarna skapat sin sociala verklighet med värden och laddningar. Konflikter i en familj balanseras vanligen av beroendet och det känslomässiga utbytet. Således innebär skapandet av en nära relation till vårdtagaren en anpassning till arbetsplatsens sociala karaktär. Starka känslomässiga bindningar kan emellertid leda till att vårdbiträdet upplever omsorgssituationen som kravfylld, men å andra sidan kan frånvaron av nära relationer i denna arbetssituation öka risken för att konflikter trappas upp.

Flera forskare har tidigare konstaterat 
betydelsen av de organisatoriska och arbetsmiljömässiga omständigheterna för vårdbiträdets och vårdtagarens upplevelser och relation till varandra (se t.ex. Svensson, 1986; Ström 1991; Szebehely, 1995).Vi har visat att förhållanden $i$ arbetsorganisationen samt dynamiken i vårdbiträdets arbetsgrupp påverkar omsorgsrelationens innehåll och kvalitet (Olsson m.fl., 1995; Olsson \& Ingvad, 1998a, 1998b; Ingvad \& Olsson, 1998). För att vi bättre ska kunna förstå hur det yttre sammanhanget påverkar karaktären i omsorgsrelationen, måste synen på samspelet mellan vårdbiträdet och vårdtagaren fördjupas och problematiseras. Denna artikel syftar till att belysa hur karaktären i relationen påverkas av skeenden $i \mathrm{dy}-$ namiken kring utbytet mellan vårdtagaren och vårdbiträdet $i$ hemtjänsten.

\section{Material}

I projektet (Olsson \& Ingvad, 1992) ingår tre kommuner, där arbetsgrupperi hemtjänsten och de tillhörande vårdtagarna följs i sex olika distrikt. Kommunerna har valts så att de representerar de vanligaste kommuntyperna iSverige med hänsyn till storlek och karaktär. KommunA är en mindre kommun (ca 9000 invånare) med tätorter av brukssamhälleskaraktär och skogsområden av glesbygdskaraktär. Kommun B (ca 25000 invånare) har som huvudort en mindre stad (ca 16000 invånare), vilken är omgiven av slättbygd. Kommun C är en stor stad (ca 250000 invånare). Kommun B och Char genomfört en tudelning av organisationen enligt beställar-utförarmodellen.

Åtta arbetsledare (områdeschefer, hemtjänstassistenter) och 82 vårdbiträden $i 10$ daggrupper har djupintervjuats. Sex av de tio daggrupperna arbetade delsi ett servicehus, dels i vårdtagarens hem utanför servicehuset, de övriga fyra grupperna enbart »ute«. Bortsett från ett bortfall på 4 vårdbiträden, har samtlig personal i de tio arbetsgrupperna intervjuats (se Olsson m.fl., 1995, för en mer utförlig beskrivning av urvalet till projektet).

För denna studie har fyra distrikt valts ut så att de ingående arbetsgrupperna representerar största möjliga avvikelser $i$ arbetsorganisation, arbetsklimat, omsorgskvalitet och arbetsmiljö jämfört med övriga daggrupper (se Olsson \& Ingvad, 1998a). I detta urval ingår grupper med både kommunal och privat arbetsgivare. Distrikten kallas här Kommunal (12 av 13 intervjuade vårdbiträden; stor stad), Privaten (6 av 7 intervjuade vårdbiträden; stor stad), Centrum (17 av 18 intervjuade vårdbiträden; mindre stad) samt Ekvallen (13 av 15 intervjuade vårdbiträden; brukssamhälle/skogsbygd). Analysen kom att bygga på 48 intervjuer av de 57 vårdbiträden som ingicki $6 \mathrm{av}$ de 10 daggrupperna. 5 intervjuer uteslöts pga. brister i dokumentationen. Vårdbiträdena, 47 kvinnor och en man, var iåldern 21 till 64 år. De hade arbetat i hemtjänsten mellan 8 månader och 28 år. Intervjuerna genomfördes under perioden januari till juni 1993.

\section{Metod}

Tematiskt strukturerade djupintervjuer användes. Intervjuerna utfördes under arbetstid i en av gruppens lokaler och varade mellan en halvtimme och drygt tre timmar. Intervjuaren (Bengt Ingvad) intog en lyssnan- 
de och bekräftande hållning; vårdbiträdet uppmuntrades att $\mathrm{i}$ hög grad själv styra det hon berättade. En intervjuarguide innehöll tema som äldre och åldrandet, hjälpinsatsen, organisationen, etc. Ett tema som växte fram under intervjuerna var »besvärliga pensionärer«. De mest centrala teman för vårdbiträdena under intervjuerna var upplevelser kring arbetet och vårdtagarna samt anpassningen till målet med arbetet. Vårdbiträdena visade en stor öppenhet $i$ sina beskrivningar av hur verksamheten upplevdes.

Intervjuerna spelades in på band och skrevs ut ordagrant av en sekreterare. Intervjuerna har bearbetats med kvalitativ metod, varvid de har genomlästs och tolkats $i$ flera omgångar. Vårdbiträdenas berättelser om vårdtagare har betraktats som uttryck för upplevelserna av relationen till dessa vårdtagare. Analysramen för intervjuerna baseras på ovanstående litteraturgenomgång och teoretiska utgångspunkter. Författarna har också en god kännedom om omsorgsarbetets karaktär genom egna erfarenheter och observationer (se Olsson \& Ingvad, 1992). I analysarbetet försökte vi tränga på djupet av vad dynamiken i relationen mellan vårdbiträdet och vårdtagaren innebär, för att på ett så mångsidigt sätt som möjligt belysa omsorgsrelationen i hemtjänsten ur denna synpunkt.»Utbytet« som ett centralt begrepp $i$ analysen växte induktivt fram ur materialet under bearbetningarna. De första genomläsningarna visade att det hade avgörande betydelse för vårdbiträdet att vårdtagaren blev nöjd med insatsen. Parternas känslor i mötet, såsom det framkom i vårdbiträdenas berättelser, uppvisade en symmetri. En negativa hållning hos pensionären motsvaras av negativa upplevelser av vårdtagaren hos vårdbiträdet. Den fortsatta analysen ledde oss till att pröva ett utbytesteoretiskt perspektiv på materialet. Begrepp, som t.ex. »latent konflikt kring förväntningarna« och »konstruktion av vårdtagaren", fram trädde som innebörder i materialet under bearbetningarna. Dessa har bildat utgångspunkt för kategorierna i resultatredovisningen nedan.

Syftet med citaten är att ge en inblickide känslor och stämningar som präglar berättelserna om omsorgsarbetet och att illustrera de kategorier och den dynamiksom framträdde i tolkningsarbetet. Urvalsprincipen har varit att citaten ska präglas av uttrycksfullhet, tydlighet och nyansrikedom. För att uppnå detta på bästa sätt har citaten valts ur ett begränsat antal intervjuer. Markeringar av pauser, emfaser, etc. har utelämnats, liksom uttryck som »..., va«. Överhoppade ord eller meningar i en citerad replik markeras med $>$... medan överhoppade repliker i ett citat markeras > (...) r. Två punkter efter ett ord står för att meningen inte är slutförd. Intervjuarens frågor är markerade med kursiv stil.

\section{Resultat}

\section{Det känslomässiga utbytet $i$ relationen}

Gemensamt för mötena i hemmet är att vårdbiträdena på olika sätt blir känslomässigt berörda oavsett vem vårdtagaren är. Vårdbiträdet ingår i ett känslomässigt förhållande till de vårdtagare hon hjälper. I en del fall har relationen en distanserad karaktär, i andra fall får den en mer intim karaktär; i en del fall skapas det så småningom en bindning. 
»Man kan ju inte älska alla. Nej, precis. På vad sätt är de olika, tycker du? Ja, en del är ju tacksamma och snälla och liksom tänker på mig och mycket så här. Och andra de bara ser till så att arbetet blir gjort." (41-årig kvinna, Ekvallen)

"Det blir liksom en del av en själv - ens vårdtagare-om man har haft dem länge.« (47-årig kvinna, Kommunal)

Mötet med den gamla berör vårdbiträdet på många sätt. Det är positivt att få känna att man har hjälpt någon och att få vara nära en annan människa. Men vårdtagarens hållning har också en stor betydelse för vårdbiträdet. Hon uppfattar att det är lättare att ge hjälp och omsorg när man får något positivt tillbaka, t.ex. tacksamhet, hjälpsamhet eller att den gamla öppnar sig och delar med sig av förtroenden:

"Är man vän med dem så blir det lättare för en själv och det blir lättare för dem, för de känner att -ja, då har man ju en bra relation." (23-årig kvinna, Privaten)

I intervjuerna uppehåller sig vårdbiträdena till en del kring betydelsen av att det går att prata med vårdtagaren. Vissa vårdtagare beskrivs som »tystlåtna", medan andra betraktas som "pratsamma«. Vårdbiträdena uppfattar att det är lättare att lära känna den senare gruppen och att utbytet med dessa blir större. Genom att prata med varandra undersöker man om man har liknande värderingar och synsätt, vilket kan betraktas som ettled i upprättandet av relationen:

»Det är svårare att prata med de som inte följer med. (...) Man känner sympati för varandra om man tycker och tänker likadant om saker och ting.» (45-årigkvinna, Ekvallen)
Speciellt uppskattar vårdbiträdena att vårdtagaren delar med sig av sina livserfarenheter och upplevelser:

"Men du vill gärna ge en bit av dig själv till pensionärerna? (...) Ja, de bjuder ju hela tiden. (...) Såpå vad sätt bjuder de på sig? Ja, detär ju det de pratar om ... de berättar ju saker de har varit med om."(21-årig kvinna, Ekvallen)

Vårdbiträdena beskriver att de förväntar sig få ett positivt gensvar. Vi menar att i vissa fall kan detta fungera som kompensation för bristande utbyte i samspelet med andra vårdtagare. I exemplet nedan jämför vårdbiträdet vad som är ett bra och dåligt utbyte för hennes del:

"Ja, kissar och bajsar och sådana besvär, det spelar ingen roll. Men hon är inte besvärlig själv, hon är inte gnällig. Hon är alltid tacksam. Därför vill jag jobba hos henne." (34-årig kvinna, Privaten)

Vårdbiträdetkan genom egna ansträngningar öka det positiva utbytet. Exempelvis beskriver många vårdbiträden att »pyssla om" vårdtagaren som en rolig uppgift. Vårdbiträdet ger av sig själv och får tillbaka pensionärens glädje:

»... som nu på kvinnor, att man kan göra dem snygga i håret, man duschar dern och klär på dem rena och snygga kläder.... piffa till dem lite grand och tycka att de är fina, och det är väldigt trevligt. Och de ser sig i spegeln och tycker: »- Javisst, det blev ju bra, jag blev ju snyggare", och så där kan de säga. Och det är väldigt roligt och få dem på gott humör." (58årig kvinna, Centrum)

Om vårdtagaren upplevs vara likgiltig, negativ, tjatig, krävande, gnällig eller inte blir 
nöjd med hjälpen så kan vårdbiträdet uppleva frustration och personlig besvikelse. Skälet till vårdtagarens negativa hållning tycks $i$ de flesta fall inte ha så stor betydelse, vårdbiträdet blir ändå negativt berörd. Att hjälpa dessa vårdtagare kan därför upplevas som påfrestande:

wa, man tycker man kämpar med någonting och försöker, och då tycker de inte om det ändå. Det är liksom - det känns rent värdelöst.«(22-årig kvinna, Privaten)

\section{Konflikter och konflikthantering}

\section{Latent konflikt kring förväntningarna}

Vårdbiträdenas berättelser visar att de förbereder sig inför svårigheter i mötet. Pensionärer som man inte har gått hem till tidigare skapar funderingar och oro:

»... även när man ska gå till en ny så kan man ju börja och tänka:»-Hur ska detnu gå? Hur ska detfungera? «(...) Och dåär man väl lite så där, när man ska gå till en ny pensionär. För att - ja, bemötande där när där kommer en ny och de reagerar.«(48-årig kvinna, Centrum)

En form av förberedelse är att ta reda på vilka förväntningar som den nya vårdtagaren har på utbytet, exempelvis genom att fråga andra vårdbiträden. Ett annat sätt är att ställa in sig på att följa gängse sociala normer och regler för vardagligt samspel, t.ex. att komma i tid, att vara snäll och trevlig. Om vårdbiträdet upplever att det går lätt att prata med pensionären kan vårdtagarens förväntningar upplevas som enklare att fastställa.Samspelet upplevs som smidigt:
"Om det är lätt att prata med pensionären så då är det ju, då faller ju pusselbitarna på plats. Det tycker jag. Då ger det ena det andra. Och då känns det bra också? Ja, det känns mycket bra.«(35-årig kvinna, Privaten)

Förberedelserna går också ut på att undersöka vad man kan förvänta av eget utbytet med vårdtagaren. Vårdbiträdet uttrycker sin hantering av problematiken kring utbytet som att man »ställer om sig « till vårdtagaren och spelar olika roller. Om en motsättning i fråga om förväntningarna blir uppenbar beskriver vårdbiträdet ofta denna med egenskaper hos vårdtagaren eller med uttalanden om »personkemin«irelationen.

»Ja, det går automatiskt. För man liksom känner ... på sig hur - vad de väntar sig av oss. Det har jag märkt på mig själv att man är avvaktande i början och iakttar och försöker vara väldigt lyhörd och lyssna och komma underfund med. ... Ja, liksom ställer in sig på en viss roll att här kan man skoja, kanske svära ibland, och sedan kan det ju vara andra som är väldigt så här sippa och kanske gudsfruktiga och så. Då får man helt enkelt hålla sig på den linjenbibeln och poesi och sådant där. (...) man vill kanske också spara sig själv att man inte ska behöva, ja, kivas om saker, helt enkelt. "(56årig kvinna, Kommunal)

Vi anser att vi kan tala om en latentinneboende konflikt kring de båda parternas förväntningar på utbytet. I allmänhet lyckas vårdbiträdet och vårdtagaren hantera konflikten. Detta sker med en viss »automatik", och i normalfallen uppkommer inte någon öppen konflikt. Det förefaller som om en process äger rum mellan vårdbiträdet och vårdtagaren kring normer och rollföreskrifter, givna i det vardagliga samspelet. I»pratet«med varandra kommer man överens om 
vilka sociala normer och inbördes roller som ska gälla i omsorgsarbetet. Vårdtagaren kan t.ex. betrakta vårdbiträdet som en gästi sitt hem eller som en familjemedlem. Ett annat alternativ kan vara att man lever upp till givna vårdbiträdes-respektive vårdtagarroller. Detta upprättande av normer och rollerskapar en plattform för utbytet mellan vårdbiträdet och vårdtagaren:

»För vissa kan man gå till var dag alltid utan att det fungerar ändå riktigt. Alltså, det fungerar ju, men inte det där att man känner att man trivs på det, som man är hemma och så.... För vissa blir det som om man är hemma hos, att man känner.« (50-årig kvinna, Centrum)

Vårdbiträdet försöker skapa en balans mellan vårdtagarens förväntningar och egna förväntningar på utbytet. Några vårdbiträden säger i intervjuerna att de tror att detär möjligt attskapa öppna överenskommelser med vårdtagaren kring hur båda vill ha det. Berättelser om hur vårdbiträdet underordnar sig vårdtagaren är dock vanliga i materialet. Underordning kan vara ettled i en strävan att skapa förtroende för arbetsförmågan och ansvarstagandet.Vårdbiträdet måste i princip först bli accepterad av vårdtagaren, för att kunna utföra sitt arbete. Har en tillit byggts upp kan detta leda till att vårdtagaren underordnar sig vårdbiträdet och accepterar omsorgsinsatsen. Då kan vårdbiträdet känna en större trygghet, eftersom hon tror sig veta att hon motsvarar vårdtagarens förväntningar. Denna trygghet liksom vårdtagarens tillit och förtroende kan ge vårdbiträdet ett positivt utbyte. Generellt sett kan generösa omsorgshandlingar, där infriandet av förväntningarna på det egna utbytet sätts åt sidan eller skjuts på framtiden, vara ett led i en strävan att undvika en öppen konflikt:

»Jag är snäll, om jag själv ska säga det. Jag accepterar de flesta. Fast, alltså man kan ju ha sin tanke där inne, men man säger det inte.... Jag gör som de vill ha det. Jag gör lite privatgrejor också, som de säger, som man inte får göra. (...) Jag tror de måste känna att man är bra, och jag vill gärna ha dem att acceptera mig.»(30-årig kvinna, Centrum)

\section{När en konflikt blir öppen}

När vårdbiträdet och vårdtagaren i sin process inte lyckas hantera de skillnader som finns i förväntningar uppstår en öppen konflikt. I exemplet nedan ringer vårdtagaren till vårdbiträdet på kvällen och vill tala om sina problem:

"Att det kan bli en för nära relation, att de kanske ställer krav på en när man är ledig ..." (21-årigkvinna, Ekvallen)

Vårdbiträdet eller vårdtagaren kan anse sig vara tvingad att ta till maktmedel i en sådan konflikt. Beskrivningar av upptrappadekonflikter förekommer inte ofta i materialet. De framställs emellertid som mycket kännbara för båda parter. I följande exempel berättar ett vårdbiträde om hur en vårdtagare upplever atthennes behov inte blir tillfredsställda och hur hon själv inte får någon bekräftelse på sitt arbete, hur mycket hon än anstränger sig. Här framträder en ond cirkel där vårdtagaren framstår som alltmer negativ:

»T.ex. - hon ville ha smör - Bregott. Men hon sa inte Rött eller Grönt. Men jag jobbar med gamla, jag tänkte:»-OK, grönt det är osaltat, bäst att jag tar Grönt."Och sedan köpte jag 
Grönt. Hon var ju så besvärlig, besvärlig. Och sedan nästa gång jag var hos henne sa hon jag var besvärlig: »- Jag har inte sovit på hela veckan, du köpte fel. «Och varför är det så, varför? ... Alltid gnällig, alltid. Hon var sur, sur.« (34-årig kvinna, Privaten)

Försök att tillämpa aktiveringsprincipen och ge »hjälp till självhjälp« innebär en risk att konflikter kring utbytet trappas upp. Vårdbiträdena utgår från att de har rätt att ställa krav på vårdtagarna. Ett vårdbiträde vill att pensionären ska hjälpa till med att göra rent hos fåglarna:

»... så sa hon:»-Ja, du har inte bytat på mina fåglar, ...«.»-Du«, sa jag, »det har jag faktiskt glömt. Men då kan du ha mål i munnen och säga att du vill ha bytat hos fåglarna, så gör jag det. «»-Nej, det vill jag inte«, sa hon. »-Varför inte det? «»-Nej, det ska du själv se.« (35-årig kvinna, Privaten)

Enstaka berättelser handlar om extremt upptrappade konflikter, där vårdtagaren och vårdbiträdet med sina känslor och handlingar är starkt involverade i meningsskiljaktigheten och agerar med maktmedel.I ett fall upplevs en handikappad man som våldsam. Pensionärens aggressiva handlingar skulle kunna tolkas som desperata maktmedel.Vårdbiträdena har beslutat att gå två till mannen och lämna honom utan hjälp om han blir aggressiv:

„Han är väldigt besvärlig. (...) Så du går dit till honom? Ja, fast han har ju slängt ut mig också. ...Du har inget emot att gå dit ändå? Nej, vi är ju två. (...) Det är vi, och så har vi då bestämt att blir han aggressiv och börjar på, så bara går vi. Det har hänt några gånger. Så får han sitta där. Men som sagt, han har varit väldigt lugn den sista tiden." (47-årig kvinna, Centrum)

\section{Konflikthanteringen}

\section{Maktutövning och tvång}

Av vårt material att döma är det mycket sällan som vårdbiträdet går in i en öppen diskussion med vårdtagaren kring hur man ska lösa en konfliktsituation. Vårdbiträdet kan i stället uppleva att hon måste överordna sig och säga ifrån:

"Man råkar ju också ut för att man får liksom skärpa tonen.... Och det är ganska jobbigt att vara tvungen att försöka tillrättavisa en som är - ändå har en aktningsvärd ålder. Men det är tvunget, man måste ibland göra det. «(36årigkvinna, Kommunal)

Ett vårdbiträde anser sig behöva använda maktmedel för att få en man att duscha regelbundet. Hon trycker på genom att hänvisa till de normer och regler som gäller på servicehuset, där mannen bor. Mannen vägrar att använda blöjor, och vårdbiträdet förhandlar från en överordnad ställning med mannen under en mycketlång tid kring detta:

"Så det fick man liksom lirka och hålla på, så att han kom in i de vanor att man duschar en gång i veckan här ... »-Det gör alla. Det ska du också göra, punkt och slut.« (...) Och så fick jag han till att använda blöjor. Det tog mig ett år ...(...) jag förklarade det att han var så illa tvungen för han var så röd och det blev mycket tvätt. Och jag fick förklara att nästan alla här i huset hade blöjor (...) Så till slut så gick han med på att prova.... Man måste vara bestämd och envis. « (47-årig kvinna, Centrum)

I en upptrappad konflikt gäller konflikthandlingarna vårdtagarens telefonsamtal vårdbiträdet upplever att pensionären utövar telefonterror. Konfliktanledningen är

Ingvad \& Olsson: Det känslomässiga utbytet och omsorgskvalitet. . . 
pensionärens krav på hjälp atthandskas med sin ångest och ensamhet. Vårdtagarens oavbrutna ringande kan här tolkas som desperata, aggressiva handlingar i en situation kännetecknad av tillgång på få maktmedel och ett upplevt underläge. Vårdbiträdetbeskriver att det enda konflikthanteringssätt som stod till buds var makt och tvång:

»För det spelade ingen roll hur mycket jag skällde och skrek att: $»-D$ u fär inte ringa mer för jag håller på med det och det. «Så ringde hon ändå och sa att: $\gg-\mathrm{Nu}$ fryser jag." "Så gick det två sekunder, så ringde hon och sa att: »-Nu var hon svettig." ... och så rev jag i sönder lappen med mitt telefonnummer. Det var enda sättet. «(50-årig kvinna, Centrum)

I mer extrema fall beskriver vårdbiträdena att de hanterar konflikter genom att ge igen, vilket tycks leda till en upptrappad ond cirkel:

"En pensionär som är lite sur, tvär och arg, liksom lite negativ och sur? Ja, då blir man mer, man tar lite mer avstånd och så där. Ja. Ja, man svarar mer liksom rakt på en sak så där. Ja, just det. Då måste man själv också bli.. Då blir man mer opersonlig ju. (...) Han gör man liksom inte det där lilla extra till.« (47-årig kvinna, Centrum)

\section{Undvikande-defensiv hantering}

Ofta hanteras konflikter genom undvikande.Att underordna sig vårdtagaren är då en vanlig strategi. Vårdbiträdet förhandlar med och utövar påtryckningar på vårdtagareniden underordnade ställningen, och hon skapar på så sätt en effektiv maktposition i omsorgsarbetet. Etti detta sammanhang allmänt uttryckär att»lirka« med vårdtagaren. Så här berättar ett vårdbiträde om hur hon får vårdtagaren att gå med på klädtvätt och attduscha:

»Ja, jag säger då t.ex.: »-Titta den är smutsig, den är inte ren, varför har du sådana kläder?" Och några dagar pratade jag. I alla fall, jag pratar, men han bestämmer." (34-årig kvinna,Privaten)

Ett vårdbiträde uppfattar att ett gammalt par behöver få städat i sin bostad, även om paret säger att deras döttrar sköter om det. Genom att underordna sig och acceptera parets vilja och genom att hänvisa till vad hon fick lov att göra förra gången, hoppas hon till slut kunna städa åt dem. Vårdbiträdet upplever det som en svår situation när paret säger nej till den omsorg hon anser att paret behöver. Hon ska ta ställning till om hon ska respektera vårdtagarens integritet eller ta ansvar för omsorgen.

Hos ett par, där kvinnan är handikappad, hanteras en upptrappad konflikt genom att vårdbiträdet försöker undvika den. Vårdbiträdet upplever att samspelet inte fungerar och gör ett byte av vårdtagaren med ett annat vårdbiträde:

"Så att det funkade liksom inte när jag gick dit, så det var bara liksom att det var inte lönt att fortsätta....Att han märkte att jag var arg på han också. Då blev det bara värre på det viset. «(50-årig kvinna, Centrum)

Man kan också avskärma sig från vårdtagaren och försöka stå ut med den känslomässiga påfrestningen då pensionären framstår som negativ, tjatig eller gnällig:

"Man svarar inte utan säger: »-Hm, ja, hm." (47-årig kvinna, Centrum) 
Arbetsgruppen representerar en möjlighet för vårdbiträdena att få utlopp för sina känslor kring vårdtagarna, och den blir på så sätt viktig $i$ vårdbiträdenas konflikthantering. Det innebär att det sker ett samspel i gruppen kring vårdtagaren, och denna process kan tänkas förstärka vårdbiträdets undvikande hantering av konflikten i omsorgssituationen och påverka de andra vårdbiträdenas förhållningssätt gentemot vårdtagaren:

"Sedan går vi ner här och dricker kaffe. Sedan berättar vi hur hemska de har varit. Då pratar man liksom av sig här. (...)... då går man bara hit och så säger man:»-Vet du vad hon sa, vet du vad hon sa?« Så, ja så babblar man ur sig alltihop och överdriver lite grand, och den förstår och.. Ja, man liksom pratar av sig det. Sedan är det klart. Det måste man ha." (47-årig kvinna, Centrum)

\section{Sociala konstruktioner i utbytet}

I exemplet ovan skapar vårdbiträdet med hjälp av gruppen en bild av vårdtagaren som i någon mening underlättar hennes hantering av konflikten. Hennes egna handlingar făr ett berättigande genom den mening hon tillskriver vårdtagarens handlingar. Genom denna typ av konstruktioner, som vi kallar "sociala konstruktioner", hanterar vårdbiträdena besvikelser och konflikter $i$ utbytet med vårdtagarna. Vi föreställer oss att man på detta sätt också kan hantera inre konflikter, t.ex. när man handlar på ett sätt som inte överensstämmer med de egna idealen angående bemötande av äldre och svaga personer. En balans i utbytet upprättas genom dessa konstruktioner.

\section{Idealisering}

Vårdbiträdet kan hemma hos vissa vårdtagare uppfatta att de är på »samma nivå«. Ömsesidighet, gemenskap och beundran för den gamla är de känslor som utmärker dessa berättelser. Man talar om en lättnad, att kunna vara sig själv och att inte behöva "ställa om sig« till pensionären. I de här fallen tycks vårdbiträdets känslomässiga utbyte vara mycket tillfredsställande och stundtals påminnande om förälskelse. Konstruktionen bygger troligen på att vårdbiträdet upplever att arbetsinsatsen uppfyller idealföreställningar om omsorgsarbetet och på vårdbiträdets känsla av att ha lyckats. Vårdbiträden talar om "favoritvårdtagare«:

»Ja, hon är alltså favoriten nästan. Hon är den roligaste av dem. Med henne kan jag prata om allting. (...) Det är ju aldrig så det går in exakt på någonting, utan detär mer vad man har hittat på i veckan och vad har man gjort $i$ helgen ...(...) hon är på samma våglängd som en annan."(21-årig kvinna, Ekvallen)

»Men det kändes aldrig som om man var där och hjälpte henne, utan det var mer som om man var där och hälsade på liksom och så ändå så tog man och damma av lite när man ändå var där." (47-årig kvinna, Centrum)

Ett vårdbiträde tillskriver sig själv ett idealiserat motiv $i$ arbetet: Det finns inte några »besvärliga" eller »favoritvårdtagare», pensionärerna måste betraktas utifrån deras behov («Florence Nightingale»). Genom att uppoffra sig för vårdtagarens bästa får hon en känsla av att vara god:

»Vilken pensionär väljer du då, om du skulle få välja? Jaha du, då skulle jag ta och välja den som var mycket otrevlig. Den personen skulle jag gå hem till (skratt). Varför det? Jo, därför

Ingvad \& Olsson:Detkänslomässiga utbytet och omsorgskvalitet... 
att hon kanske behövde den här - känna att där är någon som tycker om henne och bryr sig om henne. ... jag tror att det är ett rop på hjälp.»(45-årig kvinna, Ekvallen)

\section{Tillskrivande av egenskaper}

Ett sätt att handskas med egna negativa utbyten i omsorgsarbetet är att tillskriva vårdtagaren en eller flera negativa egenskaper, utifrån vilka hon beskrivs ensidigt. Därigenom kan man lättare härda ut påfrestningar, reducera sin involvering och rationalisera egna »förbjudna« handlingar. En vårdtagare tillskrivs egenskapen »kravfylld». Av berättelsen är det tydligt att denna konstruktion har föregåtts av en process mellan vårdbiträdet och vårdtagaren där en bindning har skapats. Inledningsvis har båda parter troligen varit generösa och förespeglat ett utbyte utöver det vanliga. Efterhand upplever vårdbiträdet vårdtagarens krav som omättliga och påfrestande:

»... han var som en morfar för mig ... Och det blev en väldigt fin kontakt med hans dotter (...)... just det där att det blir mer än jobbet kanske. (...)... vissa som man kanske kommer så nära kan bli väldigt fordrande.« (50-årig kvinna, Centrum)

Konstruktionen berättigar en mer distanserad hållning till vårdtagarna:

"Om man säger att man ger dem lillfingret, så tar de hela handen. Då känns det för mycket. ...(...) Man tar det försiktigt i början, så att man inte ska bli för mycketi det, eller hur man ska säga."(50-årig kvinna, Centrum)

Ett vårdbiträde känner sig dominerad av maken till en kvinnlig vårdtagare. Hon uppfattas som tung och svår att kommunicera med. Mannen ger inte något beröm, utan kontrollerar och kritiserar. Han försöker överordna sig och styra vårdbiträdenas arbete. Dessa upplever det obehagligt atthan blir våldsam mot sin fru. Denna man blir betraktad som »kravfylld anhörigw. Konstruktionen har till funktion att fördöma mannen och döma ut samarbetet med honom:

"... och vi gör inte det bra och han rackar ner på oss helt enkelt. Och sedan kan han då vara själv väldigt våldsam mot henne och så. (...) Alltså det att han kan liksom inte gå in i ett annat rum och låta oss sköta henne utan han ska vara och kolla hela tiden så vi gör som han tycker det ska vara. (...) För han är en sådan människa så han säger sällan tack, att det var bra eller så där. ... Krävande. " (50-årig kvinna, Centrum)

I vissa fall kan vårdbiträdet uppleva att ett gensvar uteblir, att gensvaret är negativt eller att pensionären har en allmän negativ syn på tillvaron och sig själv. Man betraktar vårdtagaren som en "negativ person«:

„Sedan är där vissa som jag sa:ibland kan man plocka ner månen till dem, de är inte nöjda för det. Vad får man för känslor för en sådan människa? Det är ju jobbigt att bara ge och ge av sig själv. Jag vet ibland innan, det var ju så jag kunde stånga huvudet blodigt. Det var ingenting som var bra. Du fick ingenting tillbaka $d \mathfrak{a}$ ? Nej, jag anser inte att jag fick någonting tillbaka.«(35-årig kvinna, Privaten)

Tidigare berördes ett fall med en man som upplevdes som våldsam av ett vårdbiträde. För vårdbiträdet består mannens respons på omsorgen av aggressivitet och misstroende. Hon förklarar detta genom att uppfatta vårdtagaren som "råbarkadk: 
"Skäller och skriker och hotar och beskyller oss för allt möjligt ...(...) Men han är misstänksam mot alla. Han har exempelvis en batong här när han är här och dricker kaffe. «(47-årig kvinna, Centrum)

Konstruktionen skänker mening åt vårdbiträdets bild av mannen:

»Hur ska man förstå det att han bär sig åt så? $\mathrm{Ja}$, jag vet inte, om det har med hela personligheten och göra eller om det har med spriten och göra ... Han har heller ingen annan.. han har väldigt dålig kontakt med sina barn också.... Det hade väl varit stridigheter alltid om jag fattade saken rätt.« (47-årig kvinna, Centrum)

Även andra vårdbiträden i arbetsgruppen konstruerar vårdtagaren på detta sätt. Ett vårdbiträde, som framhåller mannens handikapp som centralt i konflikten, upplever samspelet med mannen på ett annorlunda sätt:

»Det har också varit problem med vissa, men jag har alltid kommit bra överens med han.... Man kan kanske inte tycka så där riktigt om han, men det fungerar för mig där ... För han är inte sådan, utan han kan tacka för hjälpen och han är positiv. Så han och jag kan skoja och skratta många gånger. « (50-årig kvinna, Centrum)

Ett vårdbiträde i en annan grupp, som upplever sig tvingad att underordna sig en vårdtagare och som har svårt sig att värja mot vårdtagarens utfall, betraktar denne som "maktgalen«. Konstruktionen motiverar en undvikande-defensiv hantering av konflikten:

»En vårdtagare som liksom inte kan göra nå- gonting fel, utan det är bara fel på oss hela tiden.... Och där är man i underläge, för hon betalar oss och vi kan inte säga vad vi vill. (...) $\mathrm{Ja}$, jag tycker väldigt illa om den människan. (...) Men då bestämde jag mig för att inte diskutera någonting med henne, för jag visste att det går inte. ... Ja, så liksom där måste man verkligen dansa efter hennes pipa, ungefär, annars blir hon vansinnig." (22-årig kvinna, Privaten)

\section{Rollkonstruktioner}

Vårdbiträdet kan tolka interaktionen i omsorgsarbetet $i$ termer av att man i fantasin tilldelar sig själv och den gamle speciella roller. Därigenom blir såväl vårdtagarens som det egna agerandet $i$ kritiska lägen mer förklarligt och uthärdligt. En sådan konstruktion är att vårdbiträdena är »de som vårdtagarna avreagerar sig $p a ̊$ a. De gamla är ofta ensamma, kan man resonera, de har inte någon annan att vältra över sina sjukdomar och problem på.Vårdbiträdena får ta emot, när vårdtagarna behöver beklaga sig. Denna rollkonstruktion gör det lättare att stå ut med psykiskt tunga vårdtagare:

»Och mår de inte psykiskt bra, så är det lätt att måla allting svart. Och många har inte kontakt med mer än oss. Någon ska ju få för vad de känner inom sig, och många gånger blir det kanske vårdbiträdet som kommer dit som får det. Och då gäller det att skärma av sig som individ: »- Det är inte mig det gäller. Det är vårdtagaren det gäller. Det är hon som mår dåligt. Och då måste hon avreagera sig vad hon känner«.» (49-årig kvinna, Kommunal)

Vårdbiträden berättar om att dekan uppleva vårdtagare som deras "föräldrar«. I ett fall rationaliserar vårdbiträdet sin generösa omsorg, som egentligen är ettsätt att få med sig en motsträvig pensionär, med att uppfat-

Ingvad \& Olsson: Det känslomässiga utbytet och omsorgskvalitet... 
ta den gamla som sin moder. Rollkonstruktionen ger vårdbiträdet värdet att vara god:

„Och sedan vill jag vara bäst för henne. Jag gör mer än vad jag måste göra, därför att hon är bra. Jag tror att det är min mor.« (34-årig kvinna, Privaten)

Ett annat vårdbiträde får genom relationen till en av vårdtagarna en social status i arbetsgruppen:Hon upplever sig inte blinegativt berörd av vårdtagaren, trots att andra vårdbiträden blir det. Genom att betrakta den gamla som sin moder kan hon stå ut med den känslomässiga påfrestningen och få till stånd ett välfungerande samarbete. Möjligen betalar vårdbiträdet härigenom symboliskt av en skuld till sin verkliga mamma:

"Men, där är så många, de har svårt att gå till henne. Hon är gnällig, hon är besvärlig och det funkar inte. Och det är sådana där smågrejor, jag har aldrig haft. Jag pratar med henne som om det var min mor, liksom. Vi fungerar. Vi kan snacka och hon gnäller, men det bekommer liksom inte mig. Jag förstår henne och det fungerar jättebra.«(50-årigkvinna, Centrum)

I vårdbiträdenas berättelser kan vårdtagaren även betraktas som ett »barn«.Vad gäller fallet med upplevd telefonterror som berörts tidigare, tycker vårdbiträdet synd om pensionären och känner en moderlig omsorg om henne. Hon betraktar vårdtagaren som ett barn som inte kan ta ansvar för sig själv. Därmed kan hon förstå pensionärens störande handlingar och legitimera sin makthandling att riva itu lappen med sitt telefonnummer.

»Men hon är en sådan som man tycker om. Det gör vi allihopa. Man kan inte låta bli att tycka om henne, fast man skulle vilja vrida nacken av henne ibland. (...) Hon är inte elak, inte.Absolut inte. Utan det är väl det att man känner atthon är ensam och att det är därför som hon gör som hon gör. (...) Men hon kan nog inte själv förklara det riktigt varför hon gör det." (47-årig kvinna, Centrum)

\section{Diskussion}

Tidigare forskning har lyft fram den känslomässiga aspekten av omsorg i första hand som en egenskap som tillhör omsorgsarbetet. Man har t.ex. behandlat den som det känslomässiga engagemang för mottagaren som arbetet kräver eller som de positiva upplevelser och psykiska påfrestningar som arbetet ger (se Ungerson, 1990; Thulin, 1987; Eliasson \& Thulin, 1989). I andra fall har den känslomässiga aspekten betraktats som arbetet (vid sidan om planeringen och de praktiska sysslorna) att ta hand om vårdtagarens känslomässiga behov (se t.ex. Simonen, 1990; James, 1992). I denna explorativa studie har vi studerat den känslomässiga aspekten av omsorgsarbetet som en dynamik i förhållandet mellan vårdtagaren och vårdbiträdet. Parterna tycks ingå i ett komplicerat utbytesförhållande, där man inte bara påverkar varandra praktiskt och socialt utan också känslomässigt. De känslomässiga upplevelserna hör ihop med bl.a. de egna och den andres handlingar, känslouttryck, etc. Vi har funnit att den föränderliga karaktären i relationen mellan vårdtagaren och vårdbiträdet kan kopplas till denna dynamik. Omsorgsarbetets innehåll påverkas också av denna dynamiska process.

Det torde vara självklart att den arbetsorganisation och de regler som verksamhe- 
ten är uppbygd kring påverkar de förväntningar på utbytet som pensionären och vårdbiträdet har. Däremot har vi funnit att vårdbiträdets emotionella förväntningar på utbytet av omsorgsarbetet tycks vara oberoende av hemtjänstens organisation.I mötet med vårdtagaren blir vårdbiträdet känslomässigt berörd av dennes förhållningssätt, och hon blir således beroende av vårdtagaren i denna bemärkelse. Vår studie visar att vårdbiträdet inte bara uppskattar utan också förväntar sig att få en respons från vårdtagaren på sin omsorgsinsats. Parterna möts med förväntningar på det praktiska, sociala och känslomässiga utbytet och med föreställningar om den andres förväntningar på detta. Vårdbiträdet förefaller sträva efter att utföra den goda omsorgen om den gamla, och hon har förväntningar på positivt gensvar från denne som en bekräftelse på att hon har lyckatsi sitt arbete. I organisationen saknas ofta klara mål för vad som är ett gott arbete liksom återkopplingar som bekräftar detta arbete (Lindqvist, 1995). Och eftersom omsorgsarbetet i hemtjänsten sällan leder till att den gamlas tillstånd förbättras, är det enda resultatet av arbetet därför hur nöjd pensionären blir med hjälpinsatsen (Szebehely, 1995).Vi menar att ett positivt gensvar från pensionären svarar mot vårdbiträdets känslomässiga förväntningar på att få känna sig duktig, uppskattad och behövd.

En intressant fråga är om det finns ett specifikt förhållningssätt hos de vårdbiträden vi har intervjuat vad gäller förväntningarna på utbytet av omsorgsarbetet eller strategierna för konflikthantering som skulle vara annorlunda om majoriteten av dem hade varit män. Könsperspektivethar docki liten utsträckning varit märkbart i materia- let: vårdbiträdena har inte i sina berättelser knutit egna eller andras handlingar till om det var en kvinna eller en man. I den mån könsdimensionen blir tydlig handlar det om den känslomässiga anspänningen när manliga vårdtagare uppfattas göra sexuella närmanden. Dessa skildringar, som berör ett $\mathrm{i}$ och för sig ringa undersökt område, har förekommit i litet antal. Få berättelser har berört revirkonflikter kring kvinnornas arbete $i$ andra kvinnors hem, vilket skulle kunna tyda på att det förekommer en anpassningsprocess mellan parterna. Revir och gränssättning utgör en viktig aspekt av den dynamik som präglar omsorgsrelationen $i$ hemtjänsten. I en studie kring vårdtagares upplevelse av relationen till sina vårdbiträden har vi t.ex. kunnat visa att äldre kvinnor i större utsträckning än männen upplever att den egna kontrollen över hemmet är viktig i mötet med vårdbiträdet (Olsson \& Ingvad, 1998b). Mellan manliga vårdtagare och kvinnliga vårdbiträden präglas omsorgsrelationen mer av känslomässig bindning. Könsdimensionen kommer att analyseras ytterligare isamband med fallstudier inom projektets ram.

Vårdbiträdets förväntningar på det känslomässiga utbytet tycks ofta vara dolt för vårdbiträdet och utgör därför en underliggande källa till konflikter under omsorgsarbetet. Vår studie visar dock att vårdbiträdet och vårdtagaren i de allra flesta fall genom en anpassningsprocess till varandra i det tysta verkar hantera de ömsesidiga förväntningarna på både det praktiska, sociala och känslomässiga utbytet. Om en öppen konflikt uppkommer, hanterar vårdbiträdet ofta denna genom undvikande eller maktutövning. Det är påfallande hur sällan parterna

Ingvad \& Olsson: Det känslomässiga utbytet och omsorgskvalitet... 
tycks reflektera över eller diskutera skeenden kring konflikter tillsammans. Vi tänker oss att de underlättar anpassningen till varandra genom att anta sociala normer och roller, givna i det vardagliga samspelet. Normer om hur man bemöter äldre eller svaga människor, t.ex., kan påverka vårdbiträdets hållning i hjälprelationen, liksom hjälpberoendet $i$ en del fall kan tänkas innebära att pensionären överger en liberal äldreroll (se Tornstam, 1998) för att gå in i en tacksamhetsroll. Den gamla kan vara rädd för att annars förlora vårdbiträdets känslomässiga omsorg. Vårdbiträdet kan också uppfatta att det strider mot idealen för god omsorg att diskutera konflikter med vårdtagaren för att nå samverkan.

Sociala konstruktioner visade sig, särskilt vid öppna konflikter, ha en viktig roll $i$ vårdbiträdets hantering av de ömsesidiga förväntningarna. Attributionsteori (Heider, 1958; Jones \& Davis, 1965) ger en möjlighet att förstå dessa konstruktionsprocesser. Våra resultat överensstämmer med tidigare empiriska studier kring attribution, dvs vår automatiska benägenhet att tillskriva andra människors handlingar mening. Enligt Fincham \& Bradbury (1987) visar ett flertal studier ett samband mellan arten av attribution och graden av tillfredsställelse i äktenskap. Olyckliga makar hade till skillnad från lyckliga sådana en större benägenhet att beskriva orsaken till negativa händelser $i$ äktenskapet på ett sätt som maximerade de negativa egenskaperna hos den andra parten. Dessa makar utgick ifrån att den andra parten var orsak till det som hade hänt och att detta förhållande var givet och globalt snarare än tillfälligt och specifikt. Detta kanjämföras med attributionen »besvärliga vårdtagare « hos vårdbiträden som upplever det känslomässiga utbytet som otillfredsställande. Här finns också en koppling till vad som $i$ attributionsteori kallas för "the fundamental attribution error (Ross, 1977, sid 183), dvs att utgå från personliga faktorer hos den andra parten. Vårdbiträden i vår studie tenderade-att underskatta situationella faktorer och överskatta betydelsen av egenskaper hos vårdtagare eller anhöriga. Genom dessa attributioner skapas sociala konstruktioner som tilldelar vårdtagaren negativa egenskaper med vilka vårdbiträdet kan legitimera handlingar som står i strid med arbetsorganisationens ideal om en god omsorg (t.ex. aktivering, integritet, självbestämmande). Sociala konstruktioner som att (t.ex.) ikläda sig en modersroll kan ge vårdbiträdet ett positivt känslomässigt utbyte i samspelet med pensionären i situationer där det annars hade varit svårt att uppnå.

Vår studie tyder på attmaktdimensionen i omsorgsarbete av hemtjänstens karaktär är komplicerad.Vårdtagaren kan inte på egen hand klara sin dagliga livsföring, men hennes underläge gentemot vårdbiträdena och arbetsorganisationen är inte givet därmed. Hon kan utöva ett starkt känslomässigt inflytande på de vårdbiträden som hjälper henne. Genom att för vårdbiträdet framstå som svag och hjälplös, kontrollerande och krävande, generös och kärleksfull, etc, har pensionären möjlighet att styra vårdbiträdet och att uppfylla egna emotionella förväntningar på hjälpsituationen. Thomas (1986) påpekar exempelvis att för en pensionär som uppfattas som besvärlig kan sättet att förhålla sig i hjälpsituationen vara fråga om att inför vårdbiträdet tala om vem 
hon är och hur hon vill att andra ska se henne, i syfte att fylla ett känslomässigt behov av kontroll och trygghet. För vårdbiträdetär det fråga om starka positivt och negativt laddade krafter som är svåra att undgå och som påverkar vårdbiträdet praktiskt, socialt och känslomässigt. Det känslomässiga samspelet i relationen mellan vårdtagaren och vårdbiträdet utgör på detta sätt en central aspekt på maktdimensionen i omsorgsarbetet. En annan maktaspekt som vår studie pekar på är det samspel som sker mellan vårdbiträdena i arbetsgruppen, vilket kan mynna ut i föreställningar och förväntningar kring vårdtagare. Processen i vårdbiträdesgruppen har visat sig interagera med dynamiken i mötet mellan vårdtagaren och vårdbiträdet (se Olsson, 1998).

Det är uppenbart att dynamiken mellan vårdbiträdet och vårdtagaren påverkar kvaliteten i omsorgsarbetet. Olika typer av attribution i vårdbiträdets arbete kan bidra till omsorgskvaliteten på ett positivt eller negativt sätt. Att tillskriva vårdtagaren negativa egenskaper kan skapa brister i omsorgen, t.ex. leda till en begränsning av den känslomässiga omsorgen. Samspeleti arbetsgrup- pen eller mellan enskilda vårdbiträden kan leda till att en attribution kring en vårdtagare fastställs hos flera vårdbiträden. Gruppens bild av vårdtagaren, t.ex. som besvärlig, kan komma att prägla vårdbiträdenas förväntningar på vårdtagaren och leda till en nedåtgående spiral av ömsesidigt undvikande eller upptrappade maktmedel. Relativt sett kan då idealiseringar av omsorgsarbetet och vårdbiträdets rollkonstruktion som barn eller förälder till vårdtagaren i större utsträckning bidra till ett konstruktivt samspel mellan vårdbiträdet och vårdtagaren.

Viktiga frågor som väcks av denna studie är hur långt det är möjligt att frigöra sig från attributioner i omsorgsarbetet och vilka insatser som är lämpliga för att åstadkomma detta. Vi förordar en öppnare diskussion och friare kommunikation $i$ arbetsgrupperna kring förväntningar på och upplevelser av omsorgsarbetet. En fråga som bör lyftas frami verksamheten och i forskningen kring hemtjänsten är de emotionella förväntningar som vårdbiträden har på utbytet med pensionären i omsorgsarbetet.

\section{Summary \\ Emotional exchange and quality of care in the home help service}

The caregiver-care recipient relationship in home help service is one which involves complex processes and strong emotions. In this study, 48 home helpers in three municipalities were interviewed in depth on their perception of the relationship to the client. Six work groups were selected, using a max- imum variation sampling principle on irregularities in data, stemming from a previous study on a total of ten groups, on group climate, work environment and quality of care. It is shown that the home helpers appreciate and expect a response to their care from the client. Both parties have expecta- 
tions of an emotional exchange in the carework, and usually, in order to manage these mutual expectations, tacit processes of adjustment appear to take place. When a conflict about the expectations does become manifest, the home helper may try to avoid the conflict, e.g. by subordinating herself to the client, by screening off the client or by changing the client for another client. Or, she may feel forced to use power and to take control over the client. No evidence was found that reciprocal reflections and discussions of open conflicts are frequent. Part of the home helper's management of the expectations of the emotional exchange are social constructions, produced by attribu- tion. One group of constructions idealizes the carework. Social constructions of negative traits in the client and of roles of the parties support the home helper to endure emotional strain, reduce emotional involvement, and justify "forbidden" actions, inconsistent with the ideals of good care. The social constructions play an important role for the home helpers, but there are also implications for quality of care. They influence the home helpers' perception and expectations of the client, and, thus, affect the interaction and the care of the client. In some cases this may lead to restrictions in the care of the client.

\section{Litteratur}

Asch, S (1952) Social Psychology. New York:Prentice-Hall, Inc, Englewood Cliffs.

Barer, B (1992)The Relationship Between Homebound Older People and Their Home CareWorkers, or » The Pas de Deux « of Home Care. Journal of Gerontological Social Work, 19:1, 129147.

Bartoldus, E, Gillery, B \& Sturges, P J (1989) JobRelated Stress and Coping Among Home-Care Workers with Elderly People. Health and Social Work,August, 204-210.

Bergh,A (1995) Möte mellan mänoch kvinnori äldreomsorgen.Lund:Studentlitteratur.

Challis, D \& Davies, B (1986) Case Management in Community Care. An Evaluated Experiment in The Home Care of The Elderly. Gower:Aldershot.

Chichin, E (1992) Home Care Is Where the Heart Is: The Role of Interpersonal Relationship in Paraprofessional Home Care. Home Health Care Services Quarterty, 13:1/2, 161-177.

Christensen, K(1991)Hjemmehjælperen-en ny offentlig omsorgsrolle. Et kvindesyn på ældreomsorg. Social kritik, 12, 6-18.
Dowd,JJ(1975)Aging as Exchange:A Preface to Theory. Joumal of Gerontology, 30, 568-594.

Eliasson, Rm.fl.(1984a) Att arbeta inom äldreomsorgen, att vara pensionär och att möta varandra. En probleminventering, byggd på intervjuer med personal och pensionärer. FoU-rapport nr 3 . Stockholms socialförvaltning.

Eliasson, Rm.fl.(1984b) Att arbeta inom äldreomsorgen, att vara pensionär och att möta varandra. Underlagför diskussion och förändringsarbete. Bilaga till FoU-rapport nr 3. Stockholms socialförvaltning.

Eliasson, R \& Thulin,A-B (1989) Psykiska påfrestningar i hemtjänsten. Socialmedicinsk tidskrift, 5-6, 245-254.

Eustis, N\& Fischer, L(1991) Relationships Between Home Care Clients and TheirWorkers: Implications for Quality of Care. The Gerontologist, 31:4,447-456.

Fincham, FD \& Bradbury, TN (1987) The Impact of Attributions in Marriage:A Longitudinal Analysis. Joumal of Personality and Social Psychology, 53, 510-517.

Friedman Rosenfeld, S \& Kaye,L(1979) Homecare 
forThe Frail Elderly:Implications for an Interactional Relationship. Joumal of Gerontological SocialWork, 2:2, 109-123.

Furåker, B \& Mossberg,A-B (1997) Arbetsglädje bland anställda anhörigvårdare. Socialvetenskapligtidskrift, 4:4, 305-318.

Gordon, D \& Easton, N (1993) Patterns of Caring: Case Studies in Informal Care. Practice, 6:1, 1624.

Heider, F (1958) The Psychology of Interpersonal Relations. New York:Wiley

Ingvad, B (1992) Utvärderingaven metod för kvalitetsmätning i hemtjänsten. Rapport VI:3.Lund: Gerontologiskt Centrum.

Ingvad, B \& Olsson, E (1998) The construction of the character of the help in home help services to the elderty. Paper presented to the EBSSRS Symposium, 1998:Helsinki,June 14-16.

James, N (1992) Care = organisation + physicallabour + emotional labour. Sociology of Health \& Illness, 14:4,488-509.

Jones, EE \& Davis, KE (1965)»FromActs to Dispositions: The Attribution Process in Person Perceptions «i Berkowitz, L, red,: Advances in Experimental Social Psychology.Vol.2. New York:Academic Press.

Kaye,L (1986)WorkerViews of the Intensity ofAffective Expression During the Delivery of Home Care Services for the Elderly. Home Health Care Services Quarterly, 7:2,41-54. Kelley, HH, Berscheid, E, Christensen, A, Harvey, JH,Huston, TL, Levinger, G, McClintock, E, Peplau,LA \& Peterson,D R (1983)»Analyzing Close Relationships«i samma författare, red,: Close Relationships.NewYork:WHFreeman and Company.

Kronvall, K, Olsson, E \& Sköldborg, T(1991) Förändring och lärande. En utmaningför offentlig sektor.Lund:Studentlitteratur.

Levinger, G(1983)»Developmentand Change«i Kelley m.fl.,red,:Close Relationships. New York:WHFreeman and Company.

Lewin, K(1952) Field Theory in Social Science. Selected Theoretical Papers.London:Tavistock.

Lindqvist, H(1995) Belastningsbesväri hemtjänsten-från möten som belastar till effektiva möten som utvecklar. Centrum för Hemtjänstutveckling, Trollhättan.

Olsson, E (1988) Förändringoch konflikt. Om mellanmänskliga processeri en vårdorganisation. Lund:Studentlitteratur (Akad avh).

Olsson, E (1989) Föreläsningari socialpsykologi. Stencil.SocialhögskolaniLund.

Olsson, E (1998) Påspaning efter gruppens själ. Gruppen iteorioch praktik.Lund:Studentlitteratur.

Olsson, E \& Ingvad, B (1992) Relationens betydelse förkvaliteten i hemtjänsten. Forskningsprogram. Stencil.SocialhögskolaniLund.

Olsson, E \& Ingvad, B (1998a)»Organisationsprocesser och kvalitet i hemtjänsten. Delrapporti projektet Omsorgsrelation, organisationsförändringar och kvaliteti hemtjänsten « $i$ EdgrenSchori, M, red,: Forsa-symposium, 18-20 september 1997. Stockholms universitet, Institutionen för socialt arbete-Socialhögskolan.

Olsson, E \& Ingvad, B (1998b) Undersökningar av omsorgsklimat och gruppklimat i hemtjänsten 1995 och 1997. Stencil. Socialhögskolani Lund.

Olsson, E, Ingvad, B \& Hansson, K(1995)Arbetsorganisation och gruppklimati hemtjänsten.Socialvetenskapligtidskrift, 2:3, 227-248.

Parsons, RJ, Cox, E O \& Kimboko,P J (1989) Satisfaction, Communication and Affection in Caregiving:A View from the Elder's Perspective. Journal of Gerontological Social Work, 13:3/4, 9-20.

Peterson, D R (1983)»Conflict«i Kelley m.fl.,red,: Close Relationships. New York:WHFreeman and Company.

Qureshi,H(1990)»Boundaries between formal and informal care-giving work «iUngerson, $\mathrm{C}$, red,: Gender and Caring. Work and Welfare in Britain and Scandinavia.London:Harvester Wheatsheaf.

Raatikainen, R (1991)Dissatisfaction and insecurity of patients in domiciliary care. Joumal of $A d$ vanced Nursing, 16, 154-164.

Rook, KS (1987) Reciprocity of Social Exchange and Social Satisfaction Among OlderWomen. Journal of Personality and Social Psychology, 52:1, 145-154. 
Ross, L (1977)»The Intuitive Psychologist and his Shortcomings: Distortion in the Attribution Process « i Berkowitz, L, red,: Advances in Experimental Social Psychology.Vol. 10. New York: Academic Press.

Simonen, L(1990) Contradictions of the Welfare State, Women and Caring.Acta Universitatis Tamperensis ser A vol 295. University of Tampere (Akadavh).

Ström, P (1991) Organisationsförändringi hemtjänsten. Ettförsök attförändra organisationen tillsammansmed personalen. Rapport nr 59/ 1991. Pedagogiska institutionen, Lunds universitet.

Svensson, L (1986) Grupperoch kollektiv.En undersökning av hemtiänstens organisation i två kommuner.Stockholm:Arbetslivscentrum.

Szebehely, M (1995) Vardagens organisering. Om vårdbiträden och gamla i hemtjänsten. Lund: Arkiv (Akadavh).

Szebehely,M(1998)»Hustruns hjälp eller hemtjänstens? «i Äldreomsorgens vardag. En konfe- rensi Göteborg, 21-22 april 1998. Stockholm: Socialvetenskapliga forskningsrådet.

Thomas, A (1986) Vardagsvanoroch ritualer. Om några gamla människors möte med hemservice. FoU-rapportnr 52.Stockholms socialförvaltning.

Thulin, A B (1987) Arbetsförhållanden inom hemtjänsten. FoU-rapportnr 80. Stockholms socialförvaltning.

Tornstam, L (1998) Aldrandets socialpsykologi. Sjätte reviderade upplagan. Stockholm:Rabén Prisma.

Ungerson, C(1990) "Thelanguage of care: Crossing the boundaries i i samma författare, red,: Gender and Caring. Work and Welfare in Britain and Scandinavia.London:Harvester Wheatsheaf

Wenger, GC (1987) Dependence, Interdependence, and Reciprocity After Eighty. Joumal of AgingStudies, 1:4,355-377.

Wærness, K(1983) Kvinnoroch omsorgsarbete. Stockholm:Prisma.

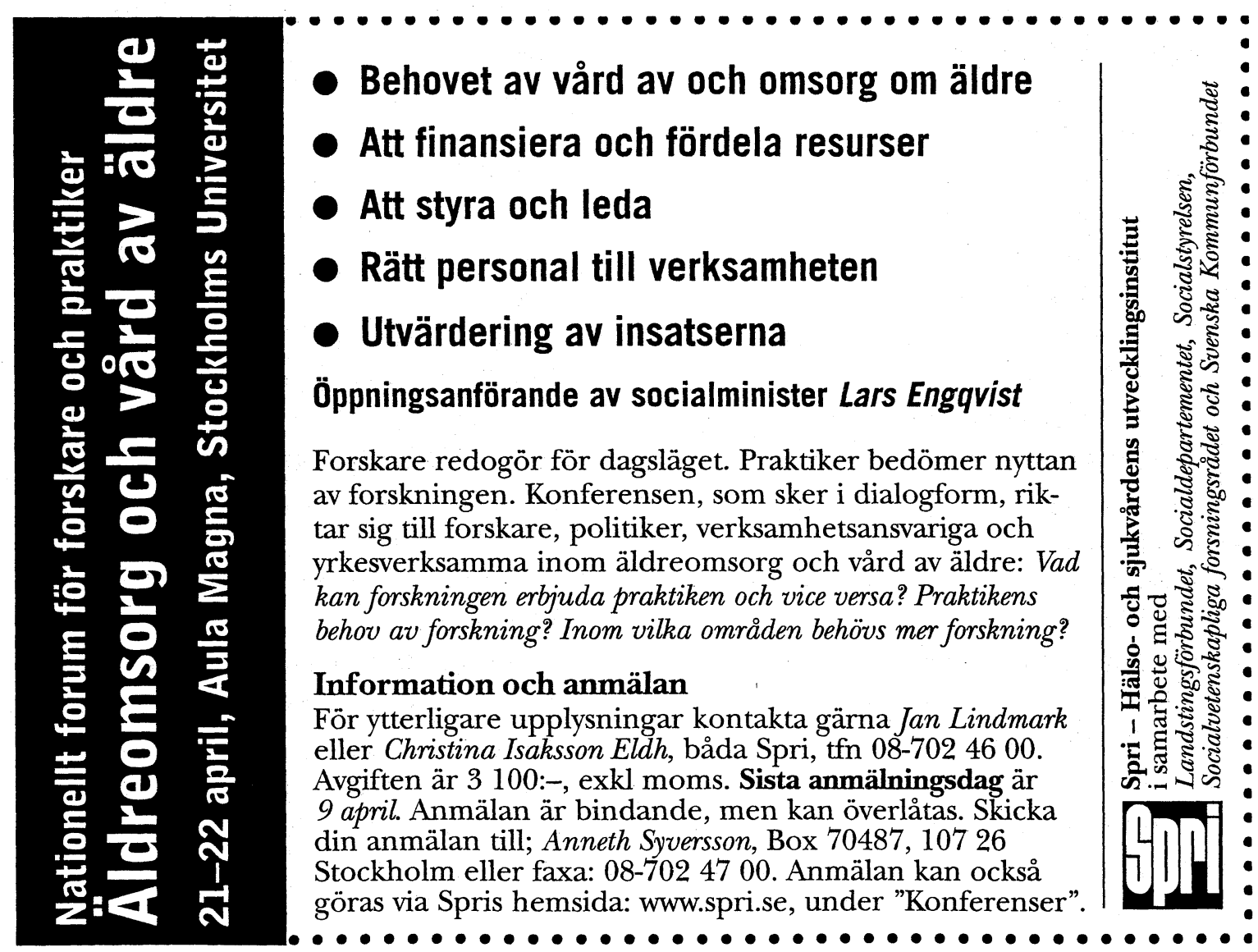

Socialvetenskaplig tidskrift nr $1 \bullet 99$ 